\title{
What Makes Student to Stay? An Exploration on Motives of Students' Withdrawal
}

\author{
Nasir $^{1, *}$, Wresni Pujiyati ${ }^{2}$, Sumarni $^{3}$, Ishaq Bagea ${ }^{1}$, Evy Segarawati Ampry $^{4}$, Badrudin ${ }^{5}$ \\ ${ }^{1}$ Department of Education Administration, Universitas Muhammadiyah Kendari, Kendari, Indonesia \\ ${ }^{2}$ Department of Education Management-Postgraduate Program, Universitas Wiralodra, Indramayu, Indonesia \\ ${ }^{3}$ Department of Education Administration, Universitas Puangrimaggalatung, Sengkang, Indonesia \\ ${ }^{4}$ Department of Education Technology, Universitas Muhammadiyah Makassar, Makassar, Indonesia \\ ${ }^{5}$ Department of Islamic Education Management, UIN Sunan Gunung Djati, Bandung, Indonesia
}

Received July 2, 2020; Revised August 17, 2020; Accepted September 11, 2020

\begin{abstract}
Cite This Paper in the following Citation Styles
(a): [1] Nasir, Wresni Pujiyati, Sumarni, Ishaq Bagea, Evy Segarawati Ampry, Badrudin, "What Makes Student to Stay? An Exploration on Motives of Students' Withdrawal," Universal Journal of Educational Research, Vol. 8, No. 10, pp. 4967 - 4974, 2020. DOI: 10.13189/ujer.2020.081069.
\end{abstract}

(b): Nasir, Wresni Pujiyati, Sumarni, Ishaq Bagea, Evy Segarawati Ampry, Badrudin (2020). What Makes Student to Stay? An Exploration on Motives of Students' Withdrawal. Universal Journal of Educational Research, 8(10), 4967 - 4974. DOI: 10.13189/ujer.2020.081069.

Copyright $\mathrm{C} 2020$ by authors, all rights reserved. Authors agree that this article remains permanently open access under the terms of the Creative Commons Attribution License 4.0 International License

\begin{abstract}
This study intends to examine factors reasoning students' withdrawal from school, and formulate strategy or model to attract and retain them until finishing their education. This research was motivated by the indicator of Rough Participation Rates and Educational Pure Participation Rates showing an imbalance. Children of compulsory school-age who register at each level of education (elementary, junior high, and high school or equivalent) are not all able to complete their schooling. This means that schools must strive to minimize the number of students' withdrawal. Although, there have been many programs launched by the government to stimulate access to education, they had not been able to increase community participation in education. Data in this research were obtained by using Google form electronic data access. It was shared to 200 students aged 12 to 16 years old from 5 different schools. However, only 174 respond it. In addition, the data were also collected through doing interviews and analyzing of the relevant documents. Present study reveals that broken home, experiencing bullying, financial matter, and disinterest in education are the students' motives dropping out school. Hence, the recommendations of strategy overcoming the issue were growing students' academic motivation, providing the quality of school services, and applying an attractive learning procedure. Scheme formulation-developed, meant to maintain students, makes
\end{abstract}

them feel at home, and remain in school.

Keywords Academic Motivation, Satisfaction, Strategy of Retention, Students' Withdrawal

\section{Introduction}

Nowdays, student retention is becoming an important issue in school life (Wild \& Ebbers, 2002). Student retention is important because students are more selective in choosing schools (Rizkallah \& Seitz, 2017). Due to, many schools have begun to develop strategies to retain students by understanding their needs and motivating them. In addition, school culture, service staff and school administrators also influence student retention (Mahan et al., 2014). Everything is taken to satisfy and maintain students so that they can graduate as alumnae and alumni.

Ascertaining the roots of students' withdrawal or dropping out of school is not an easy task. Previous studies have been dedicated to instituting the causes leading to dropping out of school. Majority of them indicate that there is not a single factor, but rather a combination of factors (Rumberger, 2011; Lamot et al., 2013). Krstić, Ivana \& Videnović (2017), state several 
groups of factors are identified: individual, familial, school and others, referred to as social, community or systemic, depending on the particular research focus, in which, Ryrie (1981) found that: more than $2 / 5$ children aged 16 years had decided to quit school from the start of their study. In his research, Ryrie concluded if the children felt bored going to school. Varlaam and Shaw (1984) also found that $3 / 5$ students in high school intend to quit school. They mean to stop at the age of 16 with the intention to start working as soon as possible instead of staying in school. Therefore, Moore (2017) identified nine causes of students quitting/leaving school, namely: 1) lack of academic preparation, 2) academic boredom, 3) difficulty managing the transition to the next level, 4) uncertainty about the long-term goals, 5) lack of -relevance of curriculum, 6) social isolation, 7) mismatch between students' expectations and initial experience, 8) low commitment to survival, and 9) financial factors. Meanwhile, based on the Indonesian Children Profile book in 2015, there are several explanations for children quitting school, including: no fees, work, marriage, feeling that education is sufficient, economic, distant school, handicapped, unaccepted and others (BPS, 2015).

One unresolved educational phenomenon is the question of participation and the opportunity to obtain education (Ustman, 2013). The puzzle of participation to achieve education is the ratio or comparison between education inputs or the number of population accommodated in education units. In this regard, this has not only become a problem in Indonesia, but also throughout the world. Even the distribution of the quality of education has not been a main agenda in many countries (Willms, 2010).

\subsection{Analysis of Situation}

In actual fact, the Constitution 1945 of the Republic of Indonesia, Article 31 paragraph (2) has stated that "every citizen is required to attend basic education and the government is obliged to prepare the disbursement". To realize the mandate of the performance, the government passed Law No. 20 of concerning the National Education System 2003. In Article 34 paragraph 2 of the National Education System Law states that, "Central and regional governments guarantee the implementation of compulsory education at the minimum level of primary and secondary education without charging fees". To be effective, it can be implemented at the Provincial, Regency and City levels. The government has also strengthened the legal basis for implementing the 12-year compulsory education through PP No. 47 of 2008 concerning Compulsory Education.

Several programs to initiate compulsory 12-year; basic education have been carried out by the Government, for example through the Universal Secondary Education program, Minister of Education and Culture Regulation No. 20 of 2013. In addition, the government provides other funding schemes to facilitate students from lowly families can still access education through the Smart Indonesia Program, Smart Indonesia Card, Student Operational Assistance, and Regional Student Operational Assistance. All of these programs are taken to improve the competitiveness of the nation and welcome demographic bonuses.

However, by seeing the report on Rough Participation Rates and Pure Participation Figures for the Education and Culture Data and BPS in 2019, the level of Rough Participation Rates in Southeast Sulawesi Province in 2018/2019 shows an unmatched ratio; elementary school is 102.75 , senior high school is 106.50 , and senior high school is 101.55. The pure Participation Rate for each school; elementary school is 88.61 , junior high school is 74.25 and senior high school is 68.26 . These data indicate that not all of children of compulsory school age who register at each level of education are able to complete their school. This means that schools must strive to minimize the number of school children who decide to quit school. These figures are not directly proportional to the spirit of 12-year compulsory basic education. Although many programs have been launched to stimulate access to education, they have not been able to increase public participation in education. Hence, researchers feel there needs to develop a strategy for student retention.

The researcher conducted an in-depth investigation to represent stakeholders all over the Southeast Sulawesi Education. From the results of the investigation, it is employed to construct a model that would be used to retain students at school. The implication it will improve student governance, school management, and education quality, increase students' Pure Participation Rates, and achieve the goal of compulsory 12 years of basic education.

\section{Research Method}

The stages of the study were initiated by conducting a survey of the schools which were the research samples. The data collection methods used were questionnaire sent (mailed questionnaire), interviews (school administrators), and relevant documents. The (mailed questionnaire) will use Google Form electronic data access in order to facilitate access to information. The questionnaire was created using Google Online Form and the link was distributed to obtain survey data. The mailed questionnaire will be distributed to students aged 12 to 16 years old from 5 schools. The selection of participants is based on a purposive basis (which has internet access). The questionnaire contains questions or statements related to motivation and level of student satisfaction as a way to keep them in school. Interviews and document analysis were also chosen to elaborate the results of the questionnaire sent. The key interview informant is the 
Head of Southeast Sulawesi Education Office. Key informant will appoint personnel in the school who are eligible to be interviewed. The next informant will follow the flow of the snowball system.

The survey results will be processed using a tabulation system. The results of the survey are tabulated in the form of a table containing data that have been coded according to the required analysis. Data processing of Google form survey results starts with the complete Response tab. Apply weights to results by creating a pivot table in which the column is the answer to the question and the datum is the number of weights. Some responses will be manually recorded and will then be deleted when viewing results that have been weighted because the Survey cannot calculate the weight of responses whose demographics are unknown. While the data from the interview will be reduced; choose which datum is relevant to use to strengthen the research report. Data reduction through the stages of the selection process, focusing on simplification, abstracting and transformation of rough data arising from field data (Miles, Huberman, \& Saldana, 2014). After reducing the data, it is further categorized. The data are categorized according to needs; Data are based on date, characteristics of informants, or research location.

The researcher displays the data, by designing a row and column of a metric and determining the type and form of data entered into the metric boxes. Likewise, it displays the data in the form of narrative, chart, flow chart, and others. In the final part, it is drawing conclusions. The conclusions written include important information in outline research. These conclusions are written in a language that is easy for the reader to understand and not convoluted.

\section{Result of the Research}

In the opening of this part, the researchers presented the number of students enrolled in school throughout the cities and districts of Southeast Sulawesi starting from elementary school level to senior high school as presented in the table (see table 1).

Table 1. Registered Students Attend All Cities and Regencies of Southeast Sulawesi

\begin{tabular}{|c|c|c|c|}
\hline \multirow{2}{*}{ Regency/City } & \multicolumn{2}{|c|}{ Registered Student } \\
\cline { 2 - 4 } & Elementry School (\%) & Junior High School (\%) & Senior High School (\%) \\
\hline Buton & 100,00 & 75,68 & 68,71 \\
\hline Muna & 98,02 & 77,99 & 71,97 \\
\hline Konawe & 99,18 & 76,70 & 64,45 \\
\hline Kolaka & 99,74 & 73,56 & 50,75 \\
\hline Konawe Selatan & 98,17 & 75,60 & 58,86 \\
\hline Bombana & 98,37 & 75,47 & 62,31 \\
\hline Wakatobi & 97,48 & 76,06 & 52,21 \\
\hline Kolaka Utara & 98,16 & 73,30 & 57,17 \\
\hline Buton Utara & 96,80 & 82,46 & 53,91 \\
\hline Konawe Utara & 98,87 & 79,90 & 63,98 \\
\hline Kolaka Timur & 96,13 & 74,68 & 63,27 \\
\hline Konawe Kepulauan & 99,58 & 88,42 & 71,50 \\
\hline Muna Barat & 98,04 & 84,87 & 80,15 \\
\hline Buton Tengah & 90,35 & 82,93 & 44,10 \\
\hline Buton Selatan & 97,95 & 87,71 & 58,65 \\
\hline Kendari & 93,65 & 69,06 & 70,20 \\
\hline Baubau & 99,60 & 81,62 & 62,87 \\
\hline Southeast Sulawesi & 97,50 & 76,64 & \\
\hline
\end{tabular}

Source: National Socio-Economic Survey March 2019 
Table 1 above draws the percentage of student listed attending school over cities and regencies of Southeast-Sulawesi (Elementry School, junior high school and junior high school) above shows the lowest percentage of compulsory school registration for children aged 16-18. While compulsory school children in junior high school age the percentage is above 76 percent and primary school the percentage is $97.50 \%$.

In the meantime, the results of interview to the head of the education and culture department in Southeast Sulawesi region stated that: "To achieve the target of completing students' withdrawal, the local government has taken strategic steps by continuing to invite school dropouts to return to school, providing scholarships to students from underprivileged families, either through BOS funds or Social Assistance from the Regional and Central Government, opening "SMP terbuka" for children who do not attend school regularly, establishing schools in vulnerable places where many children drop out of school, such as elementary school and Junior Secondary School "satu Atap", providing assistance in new classrooms, additional infrastructure for educational equipment and rehabilitation assistance, both from DAU and DAK, and opening package testing programs for those who have dropped out of school. However, these approaches have not been able to reduce the number of children dropping out of school.

As the latest update from the Central Statistics Agency of Southeast Sulawesi Province, on January 4, 2019 regarding the number of drop-in students in elementary and junior high schools in 2019 is as shown in chart (chart 1 and 2).
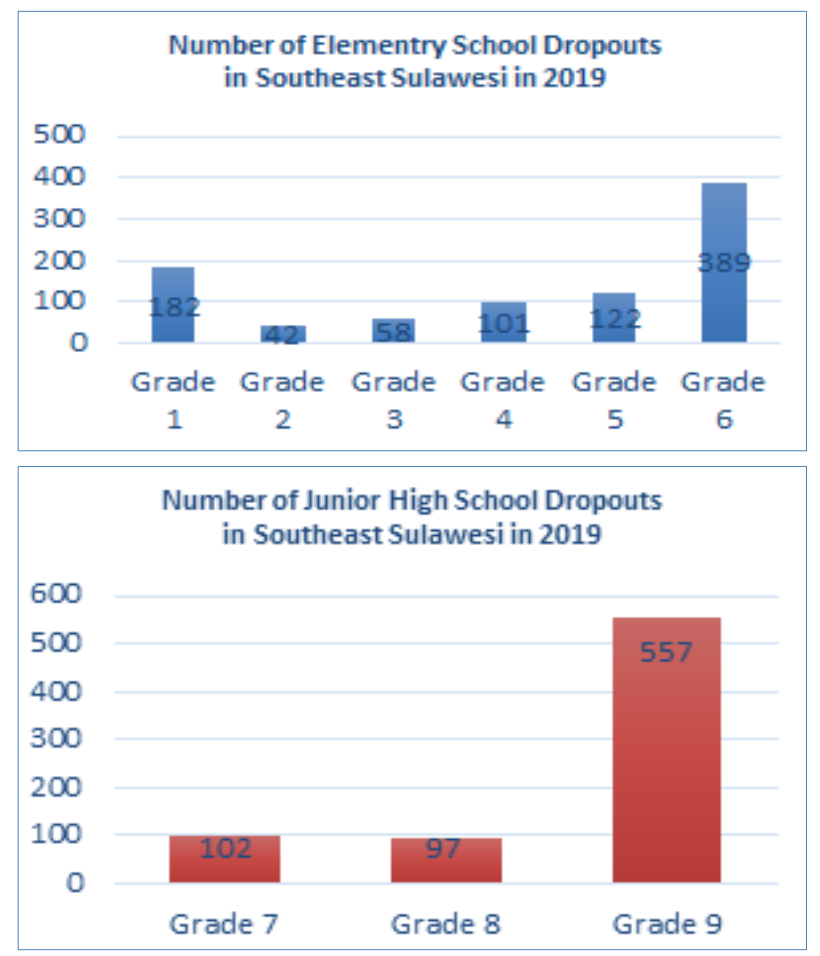

Source: Central Statistical Office of Southeast Sulawesi Province
According to the chart 1 and 2, the number of dropouts student in Southeast Sulawesi in 2018/2019 at each level (Elementry school \& junior high school) was not very high, Elementry school was $4.9 \%$ out of total 551,501 students, and junior secondary school was $16.7 \%$ out of 126,665 . However, the most significant fact is the percentage of student's dropouts in the final study period. Whereas at that time it was a period where students would complete their education in elementary school.

The percentage of dropout's students will continue to grow even more if no solution is taken for them (students who have dropped out of school). From the results of deepening the data through interviews with informants, the researchers summarized if the causes of students dropping out of school were not only due to economic factors, because basically the cost of primary and secondary education had been funded by the government through BOS funds.

Some other factors that are widely mentioned include: 1) Transferring schools because they are forced to join their parents who are transferred to other regions; 2) Problems that occur in his house; 3 ) be a victim of a fractured parent relationship; 4) students taking part in education while working part time; 5) victims of bullying; and 6) the students themselves have no interest in going to school. The measurement of each issue that is widely mentioned by the respondents as itemized in the chart (see chart 3)

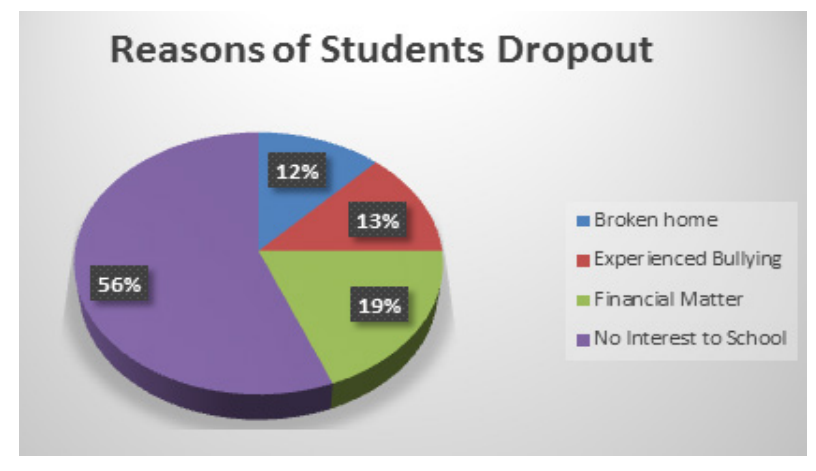

Source: Results of online survey processing (Researchers, 2020)

The Pie-chart 3 reveals about percentage of motives of Students' withdrawal taken by online survey processing. It indicates if students' disinterest in education occupies the highest percentage of $56 \%$. Students' disinterest in education is triggered by low academic motivation and unsatisfactory school services. Thus, researchers formulated strategies that will be used to increase student retention rates through academic motivation and student satisfaction with educational services. The formulation of the strategy is contained in Figure (see Figure 1).

Figure 1 displays about variables contain the formulation of student retention strategy including 1) academic motivation; 2) school's service satisfaction, and 3 ) applying proper learning approach to students. In the following session, will be elaborated more about the formulation. 


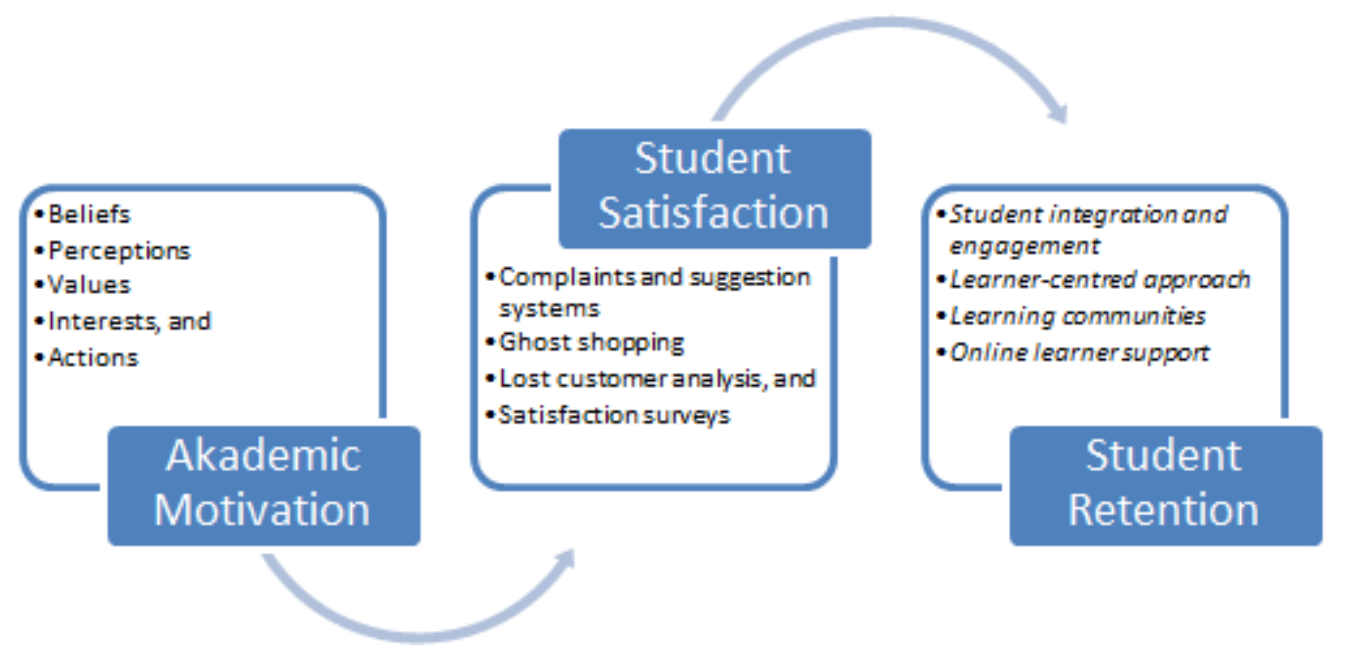

Figure 1. Student Retention Strategy through Increasing Academic Motivation and Satisfaction (Authors, 2020)

\section{Discussion}

\subsection{Academic Motivation}

Motivation regarding motives underlying a behavior (Guay et al., 2010). Meanwhile, Broussard \& Garrison (2004) broadly define motivation as an attribute that moves a person to do or not do something. Motivation involves beliefs, perceptions, values, interests, and actions. Motivation is an important foundation of academic development in students. Rowell \& Hong, (2013) term academic motivation as the pleasure of learning in schools characterized by mastery orientation; curiosity; persistence; learning challenging tasks; difficulty, and new things. Fischer \& Virgillito (2015) considers motivation synonymous with cognitive involvement, which he defines as "voluntary use of self-regulated self-directed learning strategies, such as paying attention, connecting, planning, and monitoring.

Academic motivation is indicated by the tendency of a student to perceive school as a valuable activity, like to learn, and enjoy all activities related to learning (Alivernini, et al., 2015). Meanwhile, low-student achievement shows a lack of academic motivation (Scheel et al., 2009; Wigfield, Lutz, \& Wagner, 2005). Lack of motivation also instigates students to quit and drop out of school (Azzam, 2007; Glass \& Rose, 2008).

Numerous circumtances affect academic motivation. For example: school climate, beliefs and perceptions of educators, families and social values (Eccles \& Roeser, 2011). Hence, school administrators (guidance counseling, teachers, and principals) must find ways of motivation and help students who need increased motivation (McCoach, 2002; Wang \& Pomerantz 2009). Rowell (2006) introduces assorted strategies for increasing academic motivation, such as: increasing students' talents and abilities, helping students develop attribution of beliefs that lead to the achievement of results, helping students see the value of an assignment, helping students develop mastery or learning goals, helping students set realistic goals, help students develop autonomy, help students interact with peers and school personnel.

\subsection{Student Satisfaction}

Mwiya (2017) outlines satisfaction as a condition that is felt by someone for the performance or benefit of a service or item that has fulfilled their expectations. According to Kotler \& Clarke satisfaction is the feeling of being happy or disappointed someone who was born from comparing the expected function of a product (or result) against their expectations. Thus satisfaction is a feeling of satisfaction that is shown by individuals. If the benefits of an item or service do not meet expectations, the customer is disappointed. However, if the benefits are in line with expectations, the customer is satisfied.

Tjiptono \& Chandra (2007) states that, customer satisfaction is an assessment that the product or service feature, provides a level of fulfillment related to pleasant consumption. A high level of satisfaction or pleasure will also create a high emotional bond. Satisfied consumers have a great chance of returning. Those who are satisfied are good advertisements because they will tend to tell good things to others. Conversely, consumers who are not satisfied can give reactions such as: criticism, complaints or just silent. According to Lassar, Manolis and Winsor (2000), two most prevalent and widely accepted perspectives on service quality include the SERVQUAL model and the Technical/Functional Quality framework.

There are several methods used to measure satisfaction. Methods or ways to measure satisfaction according to Saravanan (2018), namely: 1) Complaint and suggestion systems or providing broad opportunities for consumers to submit suggestions and complaints; 2) Ghost shopping or employing several people who act or act as potential consumers of the company's products and competitors, 
then they report the strengths and weaknesses of the products and competitors based on their experience in purchasing the product; 3) Lost customer analysis or contacting consumers who have stopped buying or who have moved suppliers to understand them and take corrective policies; and 4) Consumer satisfaction survey.

\subsection{Learning Approach}

Angelino et al. (2007) recommended other strategies for retention, to wit: maintaining student integration and engagement, implementing a learner-centered approach, creating learning communities, and supporting learning-based learning online (online learner support).

Student integration and engagement are activities that are designed to enhance interaction and communication with students. Student interaction and involvement encourage student motivation and display positive perceptions of the school (Topper, 2007). Examples include: school initiating telephone calls (Ali \& Leeds: 2009), informal online chat with students (Twigg, 2003) and pre-class orientation (Wojciechowski and Palmer, 2005). These activities are expected to produce a greater sense of ownership and erode the desire to quit school. The learner-centered approach aims to empower students by asking them to have constructive learning experiences (Dabbagh \& Kitsantas, 2004; Maki \& Maki, 2003). Therefore, all activities in the learner-centered approach ensure that students are the subject of the learning process.

Learning communities are designed to enable students to share different perspectives and learn collaboratively. Learning communities are expected to positively influence feelings of isolation, lack of support, and feelings of alienation from students (Roby \& Hampikian, 2002). Whereas online learner support is designed to provide the information needed for students to meet their needs related to educational programs in schools. Levy (2003) argues that education needs to adapt to the times. Therefore, school-based services must evolve to respond to student needs.

\subsection{Student Retention}

Crosling (2017); Thomas, Thomas, Crosling, and Heagney (2009) simply defined student's retention as a significant measure of the effectiveness of academic programs and processes. Student attrition led to an effort to maintain the continuity of student education processes. Thomas emphasized that student retention is a maintenance of the percentage of students who graduate or stay in school. Whereas, Seidman (2012) said that student retention is related to the desires and actions of a student to persist from the beginning of entry to completion. Maintaining student turnover will be useful for determining the health of school finances, maximizing the achievement of school vision, gaining school competitiveness, creating school culture, and maintaining existing legislation (Cotter, 2013a).

Based on the above, some recommendations for school administrators include: identifying students' initial motivation, periodically verifying or adjusting student motivation, and monitoring the persistence of student motivation (Cotter: 2013b), reaching their psychological maturity, including personality, social and academic skills (Farozin, 2019).

Finally, it is important to 1) Offer trained staff to help understand and support of student retention institutionally, 2) Employ projects that support and encourage student retention, 3) review recruiting and admission processes and forms to determine if the information gathered provides a solid foundation for retention strategies, 4) review admission and advising strategies affecting minority populations from the perspectives of retention and recruitment, 5) establish an early-warning system that lets faculty notify counselors, advisors, or tutors to assist students who are having dificulty in class, 6) Provide tutors in classes that typically have high percentages of students who have difficulties, 7) Pilot a Supplemental Instruction program, 8) Pilot cohort programs that have collaborative support systems with a team of faculty, advisors, tutors, and other support staff, as needed, and 9) Develop and implement staff-development training that will provide the schools work force with current information on the issues of student retention (Wild \& Ebbers, 2002). However, students who are the object of recent study have very different characteristics. They are students who are less motivated towards education. Therefore, collaboration between the government, parents and schools is needed. Thus, students who quit school can be minimized. First of all, the motivation of students is built, the government together with education managers provides maximum services in schools, and then learning activities are made interesting.

\section{Conclusions}

This research sum up that: the formulation of strategies to boost student retention rates is by fostering student's academic motivation, maintaining the quality of school services, and providing fascinating learning process. Academic motivation is grown by identifying their beliefs, perceptions, values, and interests. The quality of school services will be met if school administrators consistently implement complaints / suggestions programs, analyze strengths and weaknesses (own schools and competitor schools), continuous improvement of school services, and education consumer satisfaction surveys. Whereas, attractive learning practice is applying the right learning approach by maintaining student integration and involvement, applying a student-centered learning approach, creating a learning community, and 
online-based learning support.

The researchers also recommend to further researchers who have an interest in a similar topic to conduct a quantitative assessment with regard to aspects of the student retention strategy proposed in this study.

\section{Acknowledgments}

This article was composed by contributions of many parties. Therefore, the authors would like to thank all those who have contributed. Acknowledgments are also given to the Editorial Board of Universal Journal of Educational Reserach for providing outlet in publishing this journal.

All authors together contributed substantial work to this article. The first author compiles the article to completion, then other authors provide input; substance and English. Suggestions and inputs from all co-authors are then used as guidelines to perfect this article

\section{REFERENCES}

[1] Alivernini, Fabio., Cavicchiolo, Elisa., Palmerio., Laura, \& Girelli, Laura. (2015). Representations of study and students' academic motivation. Procedia - Social and Behavioral Sciences 205, (2015) $302 \quad$ - 305. Doi: 10.1016/j.sbspro.2015.09.086

[2] Ali, R. and Leeds, E. (2009). The impact of face-to-face orientation on online retention: a pilot study. Online Journal of Distance Learning Administration, Obtained through the internet:

http://www.westga.edu/ distance/ojdla/winter124/ali124.ht $\mathrm{ml}$ (accessed 24/2/2020).

[3] Angelino, L., Williams, F. and Natvig, D. (2007). Strategies to engage online students and reduce attrition rates. The Journal of Educators Online, Vol. 4, No. 2, pp.1-14.

[4] Azzam, A. (2007). Why students drop out. Educational Leadership, 64(7), 91-93.

[5] BPS. (2015). Profil Anak Indonesia. Jakarta: Kementerian Pemberdayaan Perempuan dan Perlindungan Anak (KPP\&PA).

[6] Broussard, S. C., \& Garrison, M. E. B. (2004). The relationship between classroom motivation and academic achievement in elementary school-aged children. Family and Consumer Sciences Research Journal, 33(2), 106-120.

[7] Cotter, Brittany. (2013). Paper investigates Student retention: An issue, a discussion and a way forward, for higher education professionals. Cobek Software Limited.

[8] Crosling, Glenda (2017). Student Retention in HigherEducation, a Shared Issue. In book: Encyclopedia of International Higher Education Systems and Institutions. Doi 10.1007/978-94-017-9553-1 314-1.

[9] Dabbagh, N. and Kitsantas, A. (2004). Supporting self-regulation in student-centered web-based learning environments. International Journal on E-Learning, Vol. 3, pp. $40-48$.

[10] Eccles, J. S., \& Roeser, R. W. (2011). School as developmental context during adolescence. Journal of Research on Adolescence, 21, 225-241.

[11] Farozin, Muh. (2019). Counselor Professional Identity of Counselor Profession Education. Cakrawala Pendidikan, Vol. 38, No. 1, February 2019 doi: 10.21831/cp.v38i1.22515

[12] Fischer, Heike \& Virgillito, Alfredo. (2015). Discussion paper: Academic Motivation of Students - The German Case. Technische Universität Dortmund. https://www.researchgat e.net/publication/277137846 Academic Motivation_of St udents_-_The_German_Case.

[13] Glass, R., \& Rose, M. (2008). Tune out, turn off, and drop out. American Teacher, 93(3), 8-21.

[14] Gottfried, A. E. (1990). Academic intrinsic motivation in young elementary school children. Journal of Educational Psychology, 82(3), 525-538.

[15] Guay, F., Chanal, J., Ratelle, C. F., Marsh, H. W., Larose, S. \& Boivin, M. (2010). Intrinsic, identified, and controlled types of motivation for school subjects in young elementary school children. British Journal of Educational Psychology, 80(4), 711-735.

[16] Kotler, Philip \& Kervin Lane Keller. (2009). Marketing Management13thEdition. (Alih bahasa: Bob Sabran). Jakarta: Erlangga.

[17] Krstić, Ksenija., Stepanović, Ivana \& Videnović, Marina. (2017). Student dropout in primary and secondary education in the Republic of Serbia. Psihološka istraživanja, Vol. XX (1) 2017. DOI: 10.5937/PsIstra1701027K.

[18] Lamote, C., Speybroeck, S., Van Den Noortgate, W. \&Van Damme, J. (2013). Different pathways towards dropout: the role of engagement in early school leaving. Oxford Review of Education, 39(6), 739-760. http://dx.doi.org/10.1080/03054 985.2013.854202.

[19] Lassar, W. M., Manolis, C., \& Winsor, R. D. (2000). Service quality perspectives and satisfaction in private banking, Journal of Service Marketing, 14 (3), 244-271.

[20] Levy, S. (2003). Six factors to consider when planning online distance learning programs in higher education. Online Journal of Distance Learning Administration, Vol. 6, No. 1, pp.1-19.

[21] Maki, R. and Maki, W. (2003). Prediction of learning and satisfaction in web-based and lecture courses. Journal of Educational Computing Research, Vol. 28, No. 3, pp.197219.

[22] Mahan, D., Wilson, K., J., P. J., and Luthy, M., (2014). Is retention enough? Learning and satisfaction of first-generation college seniors. Kentucky Journal of Higher Education Policy and Practice, 3(1), 1-29.

[23] McCoach, B. D. (2002). A validation study of the school attitude assessment survey. Measurement and Evaluation in Counseling and Development, 35, 66-77.

[24] Miles, Matthew B., A. Michael Huberman, and Johnny Saldana. (2014). Qualitative Data Analysis: A Methods 
Sourcebook. Thousand Oaks, CA: Sage.

[25] Moore, K. P. Andrea. (2017). Dissertation: Dropped Out: Factors That Cause Students to Leave before Graduation. Faculty of the Education Department Carson-Newman University.

https://www.cn.edu/libraries/tiny_mce/tiny_mce/plugins/fil emanager/files/Dissertations/Dissertations2017/Andrea_K Parton_Moore.pdf

[26] Mwiya B, Bwalya J, Siachinji B, Sikombe S, Chanda H, et al. (2017). Higher education quality and student satisfaction nexus: Evidence from Zambia. Creative Education, 8: 1044-1068

[27] Peraturan Pemerintah No. 47 Tahun 2008 Tentang Wajib Belajar.

[28] Pusat Data dan Statistik Pendidikan dan Kebudayaan (PDSPK). APK \& APM (Termasuk madrasah dan sederajat) tahun 2018/2019. Kementerian Pendidikan dan Kebudayaan.

[29] Rizkallah. G., Elias \& Seitz, Victoria. (2017). Understanding Student Motivation: A Key to Zeithaml, V. (1987). Defining and relating price, perceived quality and perceived value. Cambridge, MA: Marketing Science Institute.

[30] Roby, T. and Hampikian, J. (2002). The student perceptions of an online materials engineering course. Paper Presented at the ASEE Annual Conference 2002, Montreal, Canada.

[31] Rowell, L. L. (2006). Action research and school counseling: Closing the gap between research and practice. Professional School Counseling, 9, 376-384.

[32] Rowell, Lonnie \& Hong, Eunsook. (2013). Academic Motivation: Concepts, Strategies, and Counseling Approaches. Professional School Counseling, 16(3):158-17 1. DOI: 10.5330/PSC.n.2013-16.158.

[33] Rumberger, R. W. (2011). Dropping out: Why students drop out of high school and what can be done about it. Cambridge, Mass: Harvard University Press. Retrie-ved from: http://mina.education.ucsb.edu/rumberger/book/ch1.pdf

[34] Ryrie, A. (1981). Routes and Results: A study of the later years of schooling. Hodder and Stoughton for the Scottish Council for Research in Education.

[35] Saravanan, L. (2018). A study of student's satisfaction level towards service quality of teacher education colleges with special reference Erode district. Shanlax Int J Comm 6: $52-58$.

[36] Scheel, M., Madabhushi, S., \& Backhaus, A. (2009). The academic motivation of at-risk students in a counseling prevention program. Counseling Psychologist, 37(8), $1147-1178$

[37] Seidman, A. (2012). College student retention: Formula for student success. (2nd edition). Plymouth, United Kingdom: Rowman \& Littlefield Publishers, Inc.

[38] Thomas, Liz., Crosling, Glenda., \& Heagney, Margaret. (2009). Improving student retention in higher education: Improving Teaching and Learning. Autralian universities' review, vol. 51, No. 2, 2009.

[39] Tjiptono, Fandy \& Chandra, Gregorius. (2007). Service, Quality \& Satisfaction. Yogyakarta: Andi.

[40] Topper, A. (2007). 'Are they the same? Comparing the instructional quality of online and face-to-face graduate education courses'. Assessment and Evaluation in Higher Education, Vol. 32, No. 6, pp.681-691.

[41] Twigg, C. (2003). Improving quality and reducing cost: designs for effective learning. Change, Vol. 35, No. 4, pp.22-29.

[42] Undang-Undang Dasar 1945 Pasal 31 ayat 2.

[43] Undang-Undang Dasar 1945 Pasal 34 ayat (2)

[44] Undang-Undang Nomor 20 tahun 2003 tentang Sistem Pendidikan Nasional

[45] Utsman. (2013). Conference Paper: Esensi Wajib Belajar 12 tahun Sebagai Kebijakan Publik. https://www.researchgate. net/publication/320417254_ESENSI_WAJIB_BELAJAR 12_TAHUN_SEBAGAI_KEBIJAKĀN_PUBLIK.

[46] Varlaam, A. \& Shaw, A. (1984). 'Attitudes to school: a study of fifth year pupils', in Improving Secondary Schools (Hargreaves Report). London: Inner London Education Authority.

[47] Wang, Q., \& Pomerantz, M. E. (2009). The motivational landscape of early adolescence in the United States and China: A longitudinal investigation. Child Development, 80, 1271-1287.

[48] Wigfield, A., Lutz, L. S., \& Wagner, A. L. (2005). Early adolescent's development across the middle school years: Implications for school counselors. Professional School Counseling, 9, 112-119.

[49] Wild, Linda \& Ebbers, Larry. (2002 ). Rethinking Student Retention In Community Colleges. Community College Journal of Research and Practice, 26: 503- 519, 2002. DOI: 10.1080/02776770290041864

[50] Willms, J. Douglas (2010). School composition and contextual effects on student outcomes. Teachers College Record, 112 (4). 1008-37.

[51] Wojciechowski, A. and Palmer, L. (2005). Individual student characteristics: can any be predictors of success in online classes? Online Journal of Distance Learning Administration, Vol. 8, No. 2, pp.1-20. 